\title{
A 24-Year Record of Female Reproductive Dynamics in Two Sympatric Mouse Lemur Species in Northwestern Madagascar
}

\author{
Ute Radespiel $^{1}$ (D) Romule Rakotondravony ${ }^{2,3}$. \\ Solofonirina Rasoloharijaona ${ }^{2,3}$. Blanchard Randrianambinina ${ }^{2,3}$
}

Received: 22 February 2021 / Accepted: 4 October 2021 /Published online: 27 December 2021

(c) The Author(s) 2021

\begin{abstract}
Seasonal reproduction is widespread among primates but the degree of reproductive synchrony and plasticity can vary, even between closely related species. This study compares the dynamics of female reproductive seasonality in two mouse lemur species, Microcebus murinus and M. ravelobensis, in Ankarafantsika National Park, Madagascar, across 24 years. We collected 4321 records of female reproductive state from 1033 individual females (319 M. murinus, 714 M. ravelobensis). The analyses revealed disparate reproductive schedules: While female $M$. murinus showed high degrees of reproductive synchrony throughout all years, leading to the production of two successive litters, the seasonal onset of estrus (= reproductive activation) in female $M$. ravelobensis was more flexible than in $M$. murinus, starting 2-4 weeks earlier, varying by up to 4 weeks between years, and being less synchronized. $M$. ravelobensis females became reproductively active later in years with more rainfall, in particular rain in February, but the timing of reproductive activation was not related to differences in temperatures. The likelihood of early conception was significantly lower in $M$. ravelobensis than in $M$. murinus. This was partly due to delayed reproductive activation in young animals, and a lower likelihood of early conception for females with low body mass in $M$. ravelobensis. Our results suggest high, adaptive reproductive plasticity in $M$. ravelobensis that may enable individuals to respond flexibly to yearly environmental changes and expand the reproductive period under favorable conditions. These species differences in reproductive schedules may be the result of the divergent evolutionary histories of the two mouse lemur species in different parts of Madagascar.
\end{abstract}

Keywords Microcebus murinus $\cdot$ Microcebus ravelobensis $\cdot$ Reproduction · Seasonality $\cdot$ Photoperiod $\cdot$ Body mass

Handling Editor: Joanna Setchell

Extended author information available on the last page of the article 


\section{Introduction}

Reproductive seasonality is very common in primate species that live in seasonal environments (Heldstab et al., 2021; Janson \& Verdolin, 2005; Lindburg, 1987). If resource availability varies considerably throughout the year, pregnancies and lactation can be concentrated at certain times of the year to secure adequate energy supply for reproducing females or to facilitate infant growth and survival during the first crucial months after weaning (Di Bitetti \& Janson, 2000; Wright, 1999). Typically, the most critical reproductive events coincide with the period of high resource abundance. The main proximate trigger of seasonal reproduction is day length (i.e., photoperiod) (Perret \& Aujard, 2001). Nonetheless, some reproductive variation can be explained by changes in environmental factors, such as climate (temperature, rainfall) or resource availability, or by internal factors such as body condition and age (Brockman \& van Schaik, 2005; Ellis et al., 2021; Fernandez-Duque et al., 2002; Huang et al., 2012; Savini et al., 2008; Stone \& Ruivo, 2020).

Seasonal reproduction is also widespread in Malagasy lemurs and is generally regarded as an adaptation to their highly seasonal forest environments (Richard \& Dewar, 1991). It has been suggested that lemurs optimize and synchronize weaning periods with the period of highest food abundance to (1) provide infants with sufficient resources for weight gain before the onset of the subsequent lean (dry) season (Pereira, 1993a, 1993b), and (2) to allow females to build up energy reserves for future reproduction (Wright, 1999). However, there are some notable exceptions from seasonal reproduction among lemurs. For example, Daubentonia madagascariensis has rather non-seasonal reproduction, which has been explained by its reliance on animal food which is available throughout the year (Sterling, 1994). Mirza zaza also shows some reproductive plasticity, at least in captivity (Rode-Margono et al., 2015; Stanger et al., 1995), and two mouse lemur species, Microcebus mamiratra and M. margotmarshae, breed during the first part of the dry season (May-August, Rina Evasoa et al., 2018). These patterns were argued to be adaptive, since all three species inhabit the lowland humid forests in the Sambirano region, which are less seasonal than other Malagasy forest habitats and may provide sufficient food resources for breeding females even during the dry season (Rauh, 1992; Rina Evasoa et al., 2018).

The currently 25 described species of Microcebus (Hotaling et al., 2016; Schüßler et al., 2020), differ substantially in reproductive seasonality (Rina Evasoa et al., 2018). In addition to the two species with low reproductive seasonality, at least one mouse lemur species has strict photoperiodic reproductive activation (M. murinus), even in captivity when food supply, temperature, and humidity are kept constant and favorable throughout the year (Perret, 2000; Radespiel \& Zimmermann, 2001). This is unusual, as reproductive seasonality is lower in captive settings than in the wild in many primate species, although only in $6 \%$ of the lemurs studied (Heldstab et al., 2021). All M. murinus females enter their first yearly estrus within a 4-week period and give birth after a pregnancy of about 60 days in European breeding colonies and in different field sites in the 
dry deciduous forests of western and northwestern Madagascar (Hannover, Germany: Wrogemann et al. (2001); Paris, France: Perret (1982); Kirindy, Madagascar: Eberle and Kappeler (2004); Ampijoroa, Madagascar: Schmelting et al., 2000). Lactation lasts for about 7 weeks in captivity (Perret, 1992). Differences between field sites and breeding colonies mainly concern the number of successive litters produced per breeding season, which varies from one (Kirindy, Eberle \& Kappeler, 2004) to three in Mandena, Madagascar (Lahann et al., 2006) and in captivity (Perret, 1982; Wrogemann et al., 2001). Two other mouse lemur species, $M$. rufus and $M$. ravelobensis, exhibit at least moderate reproductive plasticity (Blanco, 2011; Randrianambinina et al., 2003; Rina Evasoa et al., 2018). M. rufus inhabits the seasonal montane evergreen rainforests in southeastern Madagascar and shows high reproductive synchrony that is most likely triggered photoperiodically, as all females enter their first yearly estrus within about 4 weeks during the long-day period (Blanco, 2011). However, the onset of estrus varied significantly by several weeks from year to year, and the authors suggest that this plasticity results from environmental differences between years, in addition to an effect of age on reproductive activation (Blanco, 2011). M. ravelobensis inhabits the dry deciduous forests in northwestern Madagascar (Olivieri et al., 2007; Zimmermann et al., 1998). Previous studies found that this species breeds seasonally, but estrous synchrony appeared to be reduced in this species compared to its partially sympatric congener $M$. murinus, since estrous females of $M$. ravelobensis were trapped over a period of several months instead of only about 4 weeks (Randrianambinina et al., 2003; Schmelting et al., 2000). Preliminary studies suggested an influence of body mass on the onset of the first seasonal estrus (= reproductive activation) (Randrianambinina et al., 2003), and noted indications of some reproductive variation between years (Rina Evasoa et al., 2018). However, a detailed, comparative evaluation of the long-term reproductive dynamics of $M$. ravelobensis and the sympatric $M$. murinus has not yet been conducted.

The aim of this study was to achieve a better understanding of the extent and drivers of reproductive plasticity within the genus Microcebus. We compare female reproductive dynamics of Microcebus ravelobensis and M. murinus based on capture data collected over 24 years at two study sites in Ankarafantsika National Park in northwestern Madagascar. We evaluated: (1) patterns of female reproductive seasonality, (2) yearly dynamics and the influence of climatic variation (rainfall and temperature) on reproductive activation, (3) the influence of age on the temporal distribution of estrus and pregnancies, and (4) the effect of body mass, study site, and climatic variation on the likelihood of conception during the first 4 major weeks of estrus (i.e., the likelihood of early conception).

\section{Methods}

\section{Study Site}

We conducted the study between 1995 and 2018 in two deciduous forest sites Jardin Botanique A (JBA), 30.6 ha, 16 ${ }^{\circ} 19^{\prime} 14$ ' S, 4648'25” E, 157-208 m above sea level 
(asl) and Jardin Botanique B (JBB), 5.1 ha, 16 17 '59” S, 4648'25” E, 83-95 m asl) in Ankarafantsika National Park (130,026 ha), about $85 \mathrm{~km}$ south of Mahajanga, Madagascar. We accessed both forest sites via a rectangular trail system with intersections every $25-50 \mathrm{~m}$. Rainfall seasonality is strong in the study area, with a rainy season lasting from November to April and no or very little rain falling between May and October. The local station of the Durrell Wildlife Conservation Trust (DWCT) kindly provided rainfall and temperature data. For all years between 1997 and 2015 with complete rainfall records, total rainfall per rainy season (November-April) was $1,667 \pm 569 \mathrm{~mm}(n=17$, mean $\pm \mathrm{SD})$. Total rainfall during the subsequent dry seasons (May-October) was $44 \pm 38 \mathrm{~mm}(n=17$; mean $\pm \mathrm{SD})$. Minimum temperatures vary between 11 and $28^{\circ} \mathrm{C}$ throughout the year and are lowest in the first half of the dry season between June and July. Maximum temperatures range from 24 to $42{ }^{\circ} \mathrm{C}$ and are highest in the second half of the dry season between October and November (Rakotondravony \& Radespiel, 2009). For analyses, we calculated monthly rainfall and monthly mean minimum and maximum temperatures for the 10 months preceding reproductive activation (November-August). Finally, we calculated total rainfall for all relevant rainy seasons.

\section{Data Collection}

We collected female reproductive records by capturing mouse lemurs regularly from 1995 to 2018 with the exception of one year (2012). The total number of set traps throughout these years was 72,524, but trapping was not evenly distributed between years and both forest sites. Yearly trap numbers per forest site varied between zero (JBA: 2012; JBB: 2012, 2014, 2017) and 4140 (JBA: 2015, Appendix S1). Whereas we regularly found and trapped both Microcebus murinus and M. ravelobensis in JBA, we only trapped $M$. ravelobensis in JBB until 2014. From 2015 onwards, we occasionally trapped a small number of M. murinus in JBB (Radespiel, unpublished data). Trapping success is heavily impacted by season, since mouse lemurs in general and $M$. ravelobensis in particular do not regularly enter traps when food availability is high in the forest, i.e., during the rainy season (Schmelting et al., 2000). Trapping was therefore usually confined to the dry season of a given year, except for 7 years (1996, 1999, 2000, 2005, 2008, 2014, 2016) during which we made some capture effort during the rainy season for specific research projects. During a typical capture night, we baited 90-100 traps with banana and placed in them at 0.5-2.0 m above ground at the crossing points of trails in JBA or JBB in the late afternoon. We collected all traps in the early morning (06:00-07:30) and brought captured mouse lemurs to the campsite for handling, sexing, weighing, marking, and reproductive scoring. We marked all animals individually with subcutaneously injected transponders (Trovan ID100, TELINJECT veterinärmedizinische Spezialgeräte $\mathrm{GmbH}$, Römerberg, Germany) for lifelong identification. Afterwards, we kept all animals in their respective traps with some banana pieces as food in a shady place in the camp during the day, and released them where we had captured them at dusk. Whenever we could not exclude the presence of lactating females (i.e., November-April), we checked traps at night (22:00-02:00), handled females directly in the forest under 
the light of two headlamps, and released them immediately afterwards so as not to keep females away from their infants for a long time. Two people were always involved in handling, with one person holding the animal as the other collected data.

We determined female reproductive condition by inspecting the nipples and the vulva/genital region and by belly palpation and body mass in accordance with the criteria in Rina Evasoa et al. (2018). We differentiated between open vulva (estrus), and closed vulva condition (non-estrus), and determined pregnancy by a comparatively high or increasing body mass coupled with an enlarged, hardened belly, and lactation by enlarged nipples that gave milk when applying soft pressure. These methods only allowed us to detect advanced pregnancies (i.e., during the second of 2 months, Schmelting et al., 2000) and not early pregnancies.

\section{Data Analyses}

We collected 4,321 female reproductive records for 1,033 individual female mouse lemurs from 23 study years. Yearly datasets varied in size (mean: 180, min: 0, max: 484 records per year) due to the varying trapping effort (linear regression, $r^{2}$ $=0.8349, n=24, p<0.0001$, Appendix S1). To prepare records for the analyses of temporal dynamics, we assigned them to the calendar week of collection. We pooled recaptures during any given week, resulting in one data entry per female per week. Most records were for weeks 18 to 45 (May-mid November) due to higher trappability during the dry season and higher capture effort during this time of year (Fig. 1). More records were available for Microcebus ravelobensis ( $n=3,054$ for 714 individual females) than for M. murinus $(n=1,257$ for 319 individual females), because data for $M$. ravelobensis were available from both sites, JBA ( $n=1,187$ for 315 individual females) and JBB ( $n=1,867$ for 399 individual females). In both species, most females contributed more than one weekly reproductive record per year (M. murinus: 52\%, M. ravelobensis: $61 \%$ ). Specifically, we trapped females during 1-18 weeks per year [M. murinus: $2.7 \pm$ $2.5($ mean $\pm \mathrm{SD}), \min =1, \max =18, n=472 ;$ M. ravelobensis: $2.8 \pm 2.3$ (mean $\pm \mathrm{SD}), \min =1, \max =16, n=1,100]$. The higher spatial trapping effort in JBB (90 traps on $5.1 \mathrm{ha}$ ) than in JBA (90-100 traps on $30.6 \mathrm{ha}$ ) only led to slightly elevated individual yearly data contributions for $M$. ravelobensis from JBB (mean

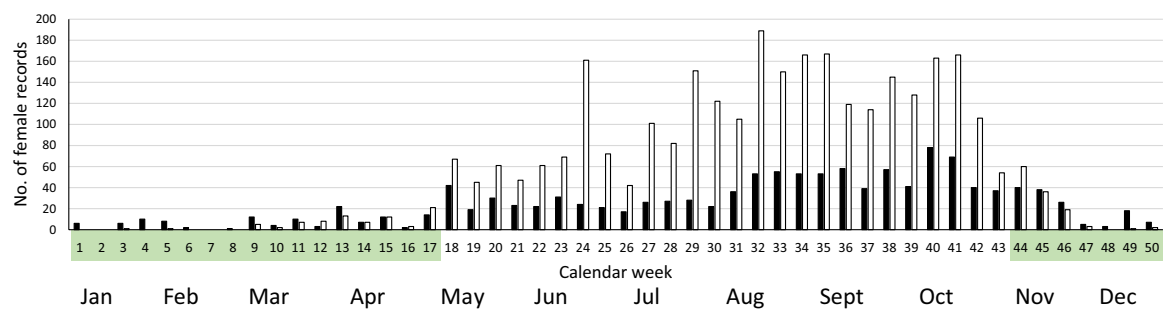

Fig. 1 Distribution of female reproductive records for M. ravelobensis (white bars, JBA/JBB) and $M$. murinus (black bars, JBA) for calendar weeks in the dry season (unmarked) and rainy season (in green) between 1995 and 2018 in Ankarafantsika, Madagascar. An indication of the start of each month is provided below the $x$ axis. 
$=2.89$ weekly entries/female, $\mathrm{SD}=2.18, \min =1, \max =15)$ compared to JBA (mean $=2.60$ weekly entries/female, $\mathrm{SD}=2.33, \min =1, \max =16$ ).

Since capture sessions in JBA and JBB typically occurred in successive weeks in any given year, we could only perform some analyses with the overall dataset and not for the study sites separately. To compare patterns of seasonal reproduction between Microcebus murinus and M. ravelobensis, we compared the occurrence of estrous, pregnant, and lactating females (expressed as \% of all captured females) for all calendar weeks and years. To explore potential differences in reproductive schedules in $M$. ravelobensis in the two study sites, we compared the weekly capture frequencies of estrus females in JBA and JBB (summed over all years) using a Spearman rank correlation test based on calendar weeks for which female trapping records were available for both sites (calendar weeks 9-46). We performed this analysis for estrus only, because this is the reproductive event with the highest frequency in the capture record, and low overall weekly frequencies for pregnancies and lactations precluded statistical analysis.

To investigate whether differences between species were stable over years, we compared the relative proportion of estrous females among all captured females for 8 specific years $(1998,1999,2000,2001,2003,2007,2008,2015)$, for which weekly coverage before and during the main weeks of the mating season (weeks 32-42) was best. We could only conduct this analysis for JBA and JBB combined, since continuous weekly capture data were not available for each site separately.

To test for potential climatic drivers of reproductive activation in Microcebus ravelobensis, we used a Spearman rank correlation test to estimate the relationships between the calendar week of first appearance of estrous females in the yearly record (for the 8 years with sufficient data, see above) and (a) total rainfall during the previous rainy season, (b) monthly rainfall during the preceding 10 months (November-August), and (c) mean monthly minimum and maximum temperatures during the preceding 10 months (November-August). We chose these 10 months because they comprise the ongoing dry and the entire previous rainy season. A Bonferroni-Holm correction for multiple testing was applied to each category of 10 monthly tests (Holm, 1979).

We also investigated the influence of age on the temporal spread of estrus events in both Microcebus ravelobensis and M. murinus. Age categorization in mouse lemurs is not a simple task, as young mouse lemurs can reach adult body mass around the beginning of their first mating season, but they continue to grow for several years (Hämäläinen, 2014; Hohenbrink et al., 2015). Moreover, mouse lemur body mass varies seasonally (Schmelting et al., 2000; Schmid \& Kappeler, 1998), and differences between years cannot be excluded (Radespiel, unpubl. data). To apply a conservative criterion, we determined one minimum adult body mass threshold for each calendar week based on the records for all recaptured females from any of the previous years. Given this definition, we categorized newly captured females that had a lower body mass than any recaptured female from any of the previous years during the same calendar week as young. We compared the proportions of estrous young and older females and the number of pregnancies for weeks $34-50$ for both species based on data for all years. 
In addition, we compared the number of conceptions vs non-conceptions during the first 4 main weeks of the species-specific reproductive season (hereafter termed "early conception", Microcebus ravelobensis: weeks 34-37, M. murinus: weeks 38-41) between species and age classes. We used the terms conception and non-conception to categorize female reproductive histories as those leading to a diagnosable stage of advanced pregnancy (conception) or not (non-conception). We diagnosed these categories based on the reproductive records of females trapped between September and November in a given year. Early conceptions led to a detectable pregnancy (increase in body mass) over the following weeks (in case of repeated capture) or were inferred (a) by a high female body mass and positive palpation results within 6 weeks of the end of the early conception period, or (b) by trapping a lactating female within 2 months after the end of the early conception period. We could apply the latter two criteria to females that were trapped only once. In contrast, we defined females as not having conceived early if they showed (a) no subsequent increase in body mass, (b) a relatively low body mass during the expected period of pregnancy, or (c) an open vulva within the subsequent 4 weeks, which does not happen during pregnancy (Wrogemann et al., 2001) unless in case of an abortion (Blanco, 2008). Premature termination of a pregnancy would also be accompanied by a drop in body mass (which the field staff never noted, so abortions were therefore probably rare). We discarded all cases for which insufficient trapping data during the late dry season precluded a decision on any of the criteria. The resulting dataset contained records for 17 study years ( $n=430$ cases). We compared the proportion of early conceptions and non-conceptions in young and adult individuals and between both mouse lemur species using non-parametric chi-squared tests. In addition, we compared the yearly proportion of early conceptions (in \%) in adult females between the two species using a Wilcoxon signed-rank test for a subset of 12 years, for which we could classify a sufficient number of females $(n \geq 3)$ as having conceived early or not in each species.

Finally, we analyzed the impact of body mass, study site (M. ravelobensis only), rainfall (total, monthly) and monthly temperatures on the likelihood of early conception (LEC) for adult females of both species during the first 4 main weeks of the species-specific reproductive season (Microcebus ravelobensis: weeks 34-37, M. murinus: weeks 38-41). We performed these analyses using generalized linear models (GLMs) or generalized linear mixed models (GLMMs) for the subset of females for which we could confirm or reject early conception (binary dependent variable, family = binomial) and for which body mass data from the 4 weeks of interest and climate data were available $\left(\mathrm{N}_{\text {rav }}=157\right.$ from 13 years, $\mathrm{N}_{\text {mur }}=63$ from 13 years). We calculated GLMMs and GLMs with the package lme4 in RStudio vs. 1.4.1717 (RStudio Team, 2020). If more than one body mass entry was available for an individual female, we calculated the median body mass for the 4-week period. The first model included body mass and study site (M. ravelobensis only) as fixed factors for each species separately. The study year did not explain significant variation in the $M$. ravelobensis dataset, so we included it as a random factor in the GLMM for M. murinus only. As a subsequent step, we calculated separate univariate GLMs for each of the 31 climatic fixed factors (total rainfall during the last rainy season, and rainfall data, minimum temperatures, and maximum temperatures for each of the 10 months from November 
to August individually) for each species. We combined all significant variables in one final full model for each species. From this full model, we derived the best model with the highest statistical support and models with similarly low AICc values $(\Delta \mathrm{AICc}<2)$ by applying the 'dredge' function with the MuMIn package.

Based on the body mass of females that conceived early, we screened the capture history of the heavier ( $>55 \mathrm{~g}$ ), non-conceptive females of M. ravelobensis for further potential explanations. We also determined rough estimates (in weeks) of interestrus intervals for females with successive estrous periods.

\section{Ethical Note}

Mouse lemurs are very small, cryptic, nocturnal, arboreal animals, and reproductive records cannot be obtained without trapping and handling individuals. Trapping with Sherman live traps is a standard procedure that is well established and widely used for mouse lemurs in many parts of the island. It does not evoke aversive responses, as many individuals are trapped multiple times during one season. We typically released animals at dusk on the handling day at their individual capture location, which imposes no disruption to their social network since individual mouse lemurs sleep away from their sleeping group temporarily under natural conditions (Radespiel et al., 2003; Weidt et $a l ., 2004)$. Trapping and handling procedures adhered to all legal requirements of Madagascar, and were approved yearly as part of our research projects by the relevant Malagasy authorities. These included the Commission Tripartite of the Malagasy government, the Department des Eaux et Forêts (DEF) — now the Ministry of Environment and Sustainable Development, the members of $C A F F / C O R E$, and the Association pour la Gestion des Aires Protégées (ANGAP) — now Madagascar National Parks (MNP). The study adhered to the "Code of Best Practices for Field Primatology" of the International Primatological Society, the "Principles for the Ethical Treatment of Non-Human Primates" of the American Society of Primatologists, and the "Guidelines for the treatment of animals in behavioural research and teaching" in Animal Behaviour (Buchanan et al., 2012). The authors declare that they have no conflict of interest.

Data Availability The datasets analyzed during the current study are available from the corresponding author on reasonable request.

\section{Results}

\section{Dynamics of Reproductive Seasonality}

Microcebus ravelobensis and M. murinus were both seasonal breeders in the study region (Fig. $2 \mathrm{a}-\mathrm{c})$. We obtained 390 estrous records $\left(n_{\text {M.rav. }}=275, n_{\text {M.mur. }}=\right.$ $115)$ during the 24 study years. We never trapped an estrous female $M$. murinus in weeks 11-36, but regularly found estrous females (> 10\%) in weeks 38-42 (i.e., from mid-September to mid-October), in week 47, and in weeks 9-10 (Fig. 2a). In contrast, we trapped a few $(<5 \%$, weekly $n=1-6)$ estrous $M$. ravelobensis 

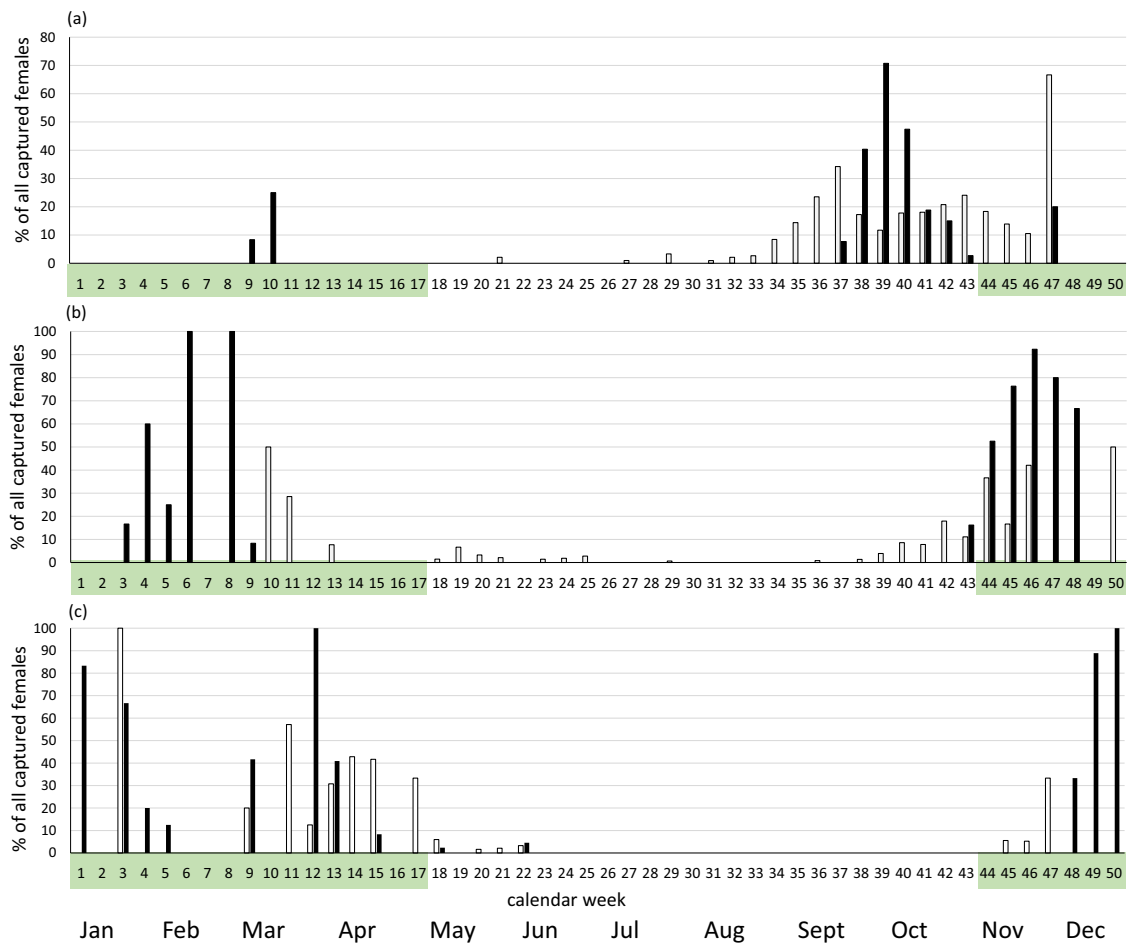

Fig. 2 Relative proportion of estrous (a), pregnant (b), and lactating (c) females among all captured females for all calendar weeks for Microcebus ravelobensis (white bars) and M. murinus (black bars) between 1995 and 2018 in Ankarafantsika, Madagascar. In green: rainy season. An indication of the start of each month is provided below the $x$ axis.

females in weeks 21-33, and noted a higher proportion ( $>5 \%$ ) of estrous females during an extended period in weeks 34-47, with peaks in weeks 37, 43, and 47. The numbers of weekly estrous records of $M$. ravelobensis from JBA and JBB were significantly and strongly correlated $\left(r_{\text {Spearman }}=0.833, n=39, p<0.0001\right.$, Appendix S2).

We also trapped pregnant females of both species seasonally $\left(n_{\text {M.rav. }}=115\right.$, $n_{\text {M.mur. }}=99$ records). We trapped pregnant females of Microcebus murinus in weeks 43-48 and again in weeks 3-9 (Fig. 2b). We never trapped pregnant M. murinus in weeks $10-42$. We trapped pregnant $M$. ravelobensis mainly ( $>10 \%)$ in weeks $42-50$ and again in weeks $10-11$. However, we also recorded a few pregnancies $(<5 \%$, weekly $n=1-13$ ) in weeks 13 - 29 and again in weeks 36-41. No more than $50 \%$ of all trapped females of $M$. ravelobensis were pregnant at any given time.

We also captured lactating females seasonally $\left(n_{\text {M.rav. }}=38, n_{\text {M.mur. }}=56\right.$ records). We trapped lactating Microcebus murinus in weeks 48-5, weeks 9-13, and with single weekly cases until week 22 (Fig. 2c). We trapped lactating $M$. ravelobensis in weeks 45-3, again in weeks $9-17$, and less often $(<5 \%$, weekly $n$ =1-4) in weeks 18-22. 
Overall, Microcebus ravelobensis started yearly reproduction earlier during the dry season and had a less synchronized and more extended reproductive season than $M$. murinus. In addition, the yearly variation in reproductive activation differed between the two species (Fig. 3). Whereas we never trapped estrous M. murinus before week 37 (mid September) and estrus mainly occurred within 4 weeks across the years (Fig. 2a, Fig. 3b), we trapped estrous M. ravelobensis in calendar weeks 34-35 in some years $(1998,1999,2001,2003)$ but only later (weeks 36-37) in other years $(2000,2007,2008,2015$, Fig. 3a). Within a single year, we trapped estrous $M$. ravelobensis during 6-9 weeks, a longer and more variable period than for $M$. murinus.

The yearly week of first seasonal estrus (weeks 34-37 for the 8 study years with sufficient data) correlated significantly and positively with the amount of rainfall in February and during the entire previous rainy season (Appendix S3). The more rain fell during February and during the entire previous rainy season, the later female Microcebus ravelobensis became reproductively active. However, we detected no such significant correlation for any other month (November-August, Appendix S3). In addition, we found no significant relationship between the week of reproductive activation and the mean monthly minimum or maximum temperatures for all 10 previous months (November-August, Appendix S3).

\section{Influence of Age and Species on Reproduction}

Whereas young and adult Microcebus murinus showed very similar temporal estrous and pregnancy dynamics (Fig. 4a), the two age classes of $M$. ravelobensis differed in reproductive dynamics (Fig. 4b). While estrous females of M. ravelobensis were mostly adult between weeks 34-38, young females were observed in estrus later and more frequently $(>10 \%$ ) only after week 38. Congruently, the few detected pregnancies of young females $(n=2$, week 45) were detected 9 weeks later than the earliest pregnancy recorded in adult $M$. ravelobensis.

Based on all available cases of early conceptions and non-conceptions in both species ( $n_{\text {M.rav./weeks 34-37 }}=320, n_{\text {M.mur./weeks 38-41 }}=110$ females), Microcebus ravelobensis conceived early less frequently $(n=67,21 \%)$ than M. murinus $(n=$ $82,75 \%$, Chi-squared test: $\left.\mathrm{Chi}^{2}=103.89, \mathrm{df}=1, p<0.00001\right)$. Early conception frequencies in adult females did not differ significantly between the two study sites in $M$. ravelobensis $\left(\mathrm{Chi}^{2}{ }_{J B A / J B B}=1.07, \mathrm{df}=1, p=0.3013\right.$, Fig. 5). The asymmetry between the species remained visible when we split the dataset into adult and young females (Fig. 5). While we detected significantly fewer conceptions in young than in adult females of both species $\left(\mathrm{Chi}^{2}{ }_{\text {murinus }}=9.23 \mathrm{df}=1, p=0.0024 ; \mathrm{Chi}^{2}{ }_{\text {ravelobensis }}\right.$ $=14.95$, df $=1, p=0.0001)$, even young M. murinus (39\%) conceived early more frequently than adult female $M$. ravelobensis at either study site (Fig. 5) and in both sites taken together (25\%). However, this difference was not significant, possibly due to the small sample size for young $M$. murinus $\left(\mathrm{Chi}^{2}\right.$ young murinus/ad. ravelobensis $=1.24$, $\mathrm{df}=1, p=0.2660)$. We never found young $M$. ravelobensis that conceived during the early conception period. 


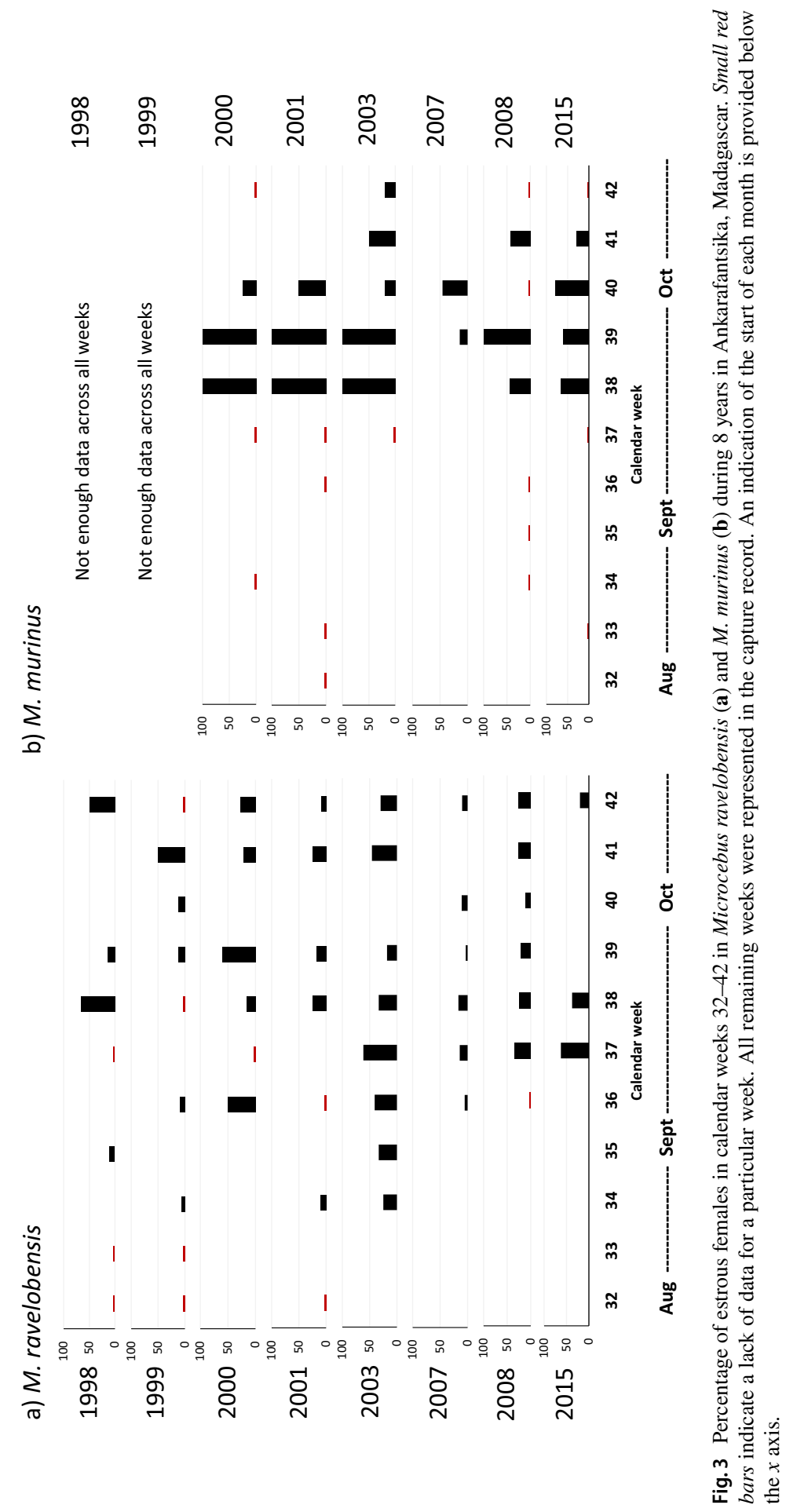


(a)

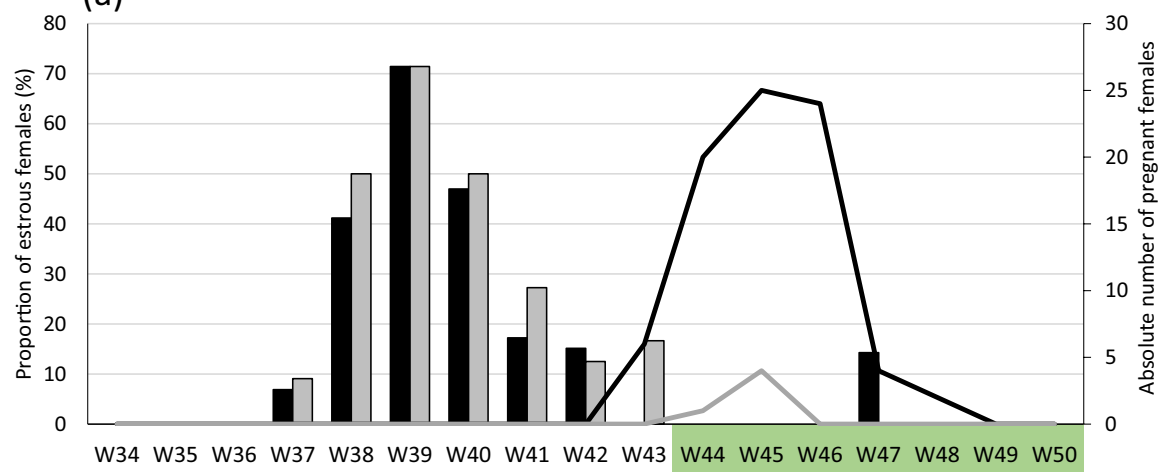

(b)

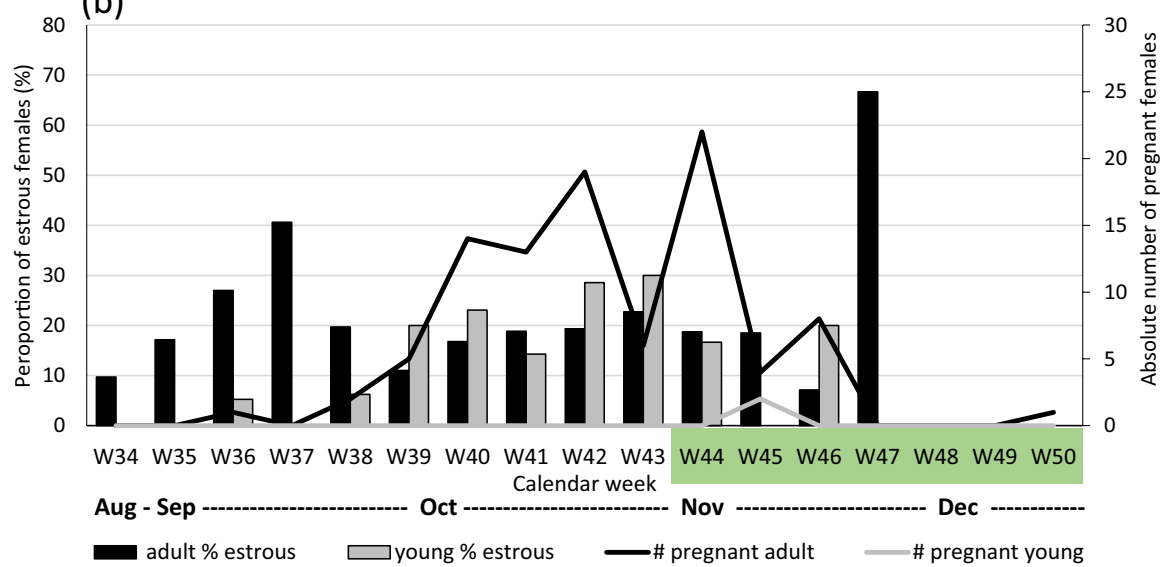

Fig. 4 Percentage (bars, left $y$-axis) of estrus females and absolute number (lines, right $y$-axis) of pregnancies in young (gray) and adult (black) Microcebus murinus (a) and M. ravelobensis (b) for calendar weeks 34-50 between 1995 and 2018 in Ankarafantsika, Madagascar. W: calendar week. In green: rainy season. An indication of the start of each month is provided below the $x$ axis.

The proportion of early conceptions in adult female M. ravelobensis was generally higher in years with early reproductive activation (years 1998/1999/2001/2003: $22-40 \%$ ) than in years with late reproductive activation (years 2000/2007/2008/2015: $0-22 \%)$. However, for all years with sufficient data $(n=12)$, adult female $M$. ravelobensis had significantly lower rates of early conceptions (mean \pm SD: $30 \% \pm$ $15 \%$, median $=27 \%$, $\min =10 \%, \max =66 \%$ ) than adult female $M$. murinus (mean \pm SD: $87 \% \pm 17 \%$, median $=100 \%, \min =56 \%, \max =100 \%$ early conceptions, Wilcoxon paired rank test: $\mathrm{Z}=3.059, n=12, p=0.0022$, Fig. 6).

\section{Influence of Body Mass, Study Site, and Climate on Conception Likelihoods}

The likelihood of early conception (LEC) (during weeks 34-37) increased significantly with increasing body mass in Microcebus ravelobensis but did not depend 


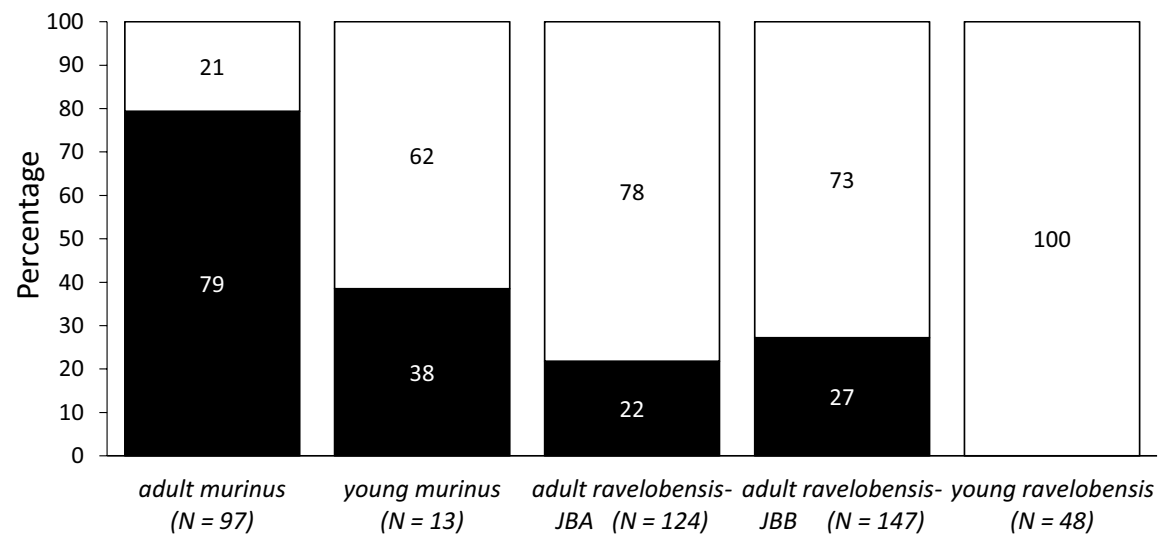

Fig. 5 Percentage of conceptions (black) vs non-conceptions (white) in young and adult females during the early conception period in Microcebus ravelobensis (weeks 34-37, JBA and JBB shown separately) and M. murinus (weeks 38-41) during 17 years between 1995 and 2015 in Ankarafantsika, Madagascar. Total sample sizes are provided below each column.

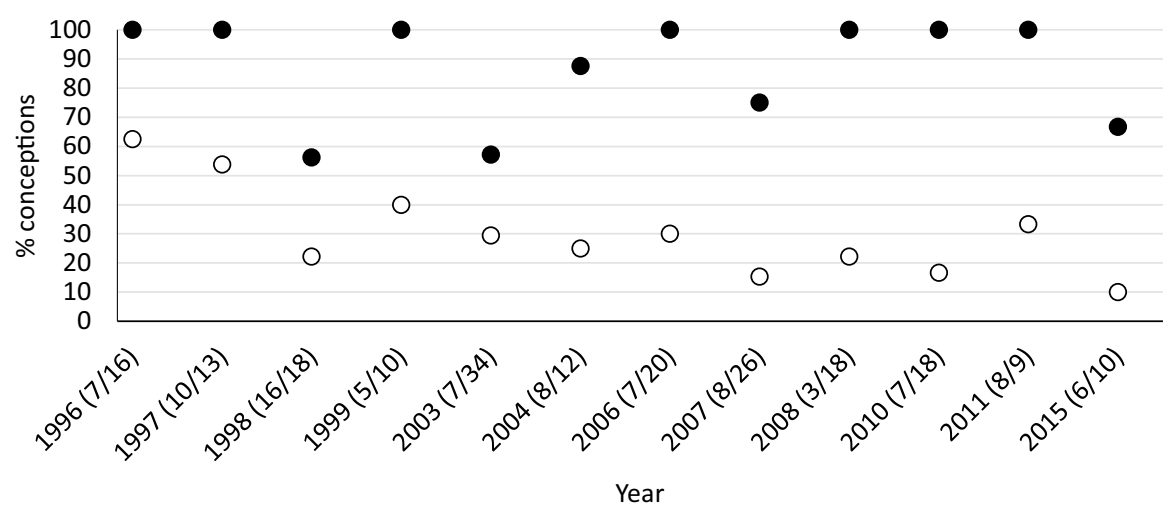

Fig. 6 The percentage of females conceiving during the early conception period in $M$. ravelobensis (weeks 34-37, white circles) and M. murinus (weeks 38-41, black circles) during 12 years between 1996 and 2015 in Ankarafantsika, Madagascar. Numbers in brackets give the yearly absolute sample sizes for this analysis $\left(n_{\text {M. murinus }} / n_{M . \text { ravelobensis }}\right)$.

on study site $\left(\mathrm{GLM}\right.$, Estimate ${ }_{\text {body mass }}=0.15460, \mathrm{SE}=0.03496, p<0.00001$; Estimate $_{\text {study site }}=0.48802, \mathrm{SE}=0.45618, p=0.2850$, Fig. 7). Among all climatic variables, only the minimum temperature in March and the rainfall in April had a significant effect on the conception likelihoods in M. ravelobensis when tested alone (Appendix S4). Whereas higher minimum temperatures in March coincided with a reduction in the LEC (Estimate $=-0.5179, \mathrm{SE}=0.2417, p=$ 0.0321 ), higher rainfall in April coincided with a higher LEC (Estimate $=0.0118$, $\mathrm{SE}=0.0060, p=0.0492)$. However, when we combined the significant climatic variables with body mass in one model, only body mass explained significant 


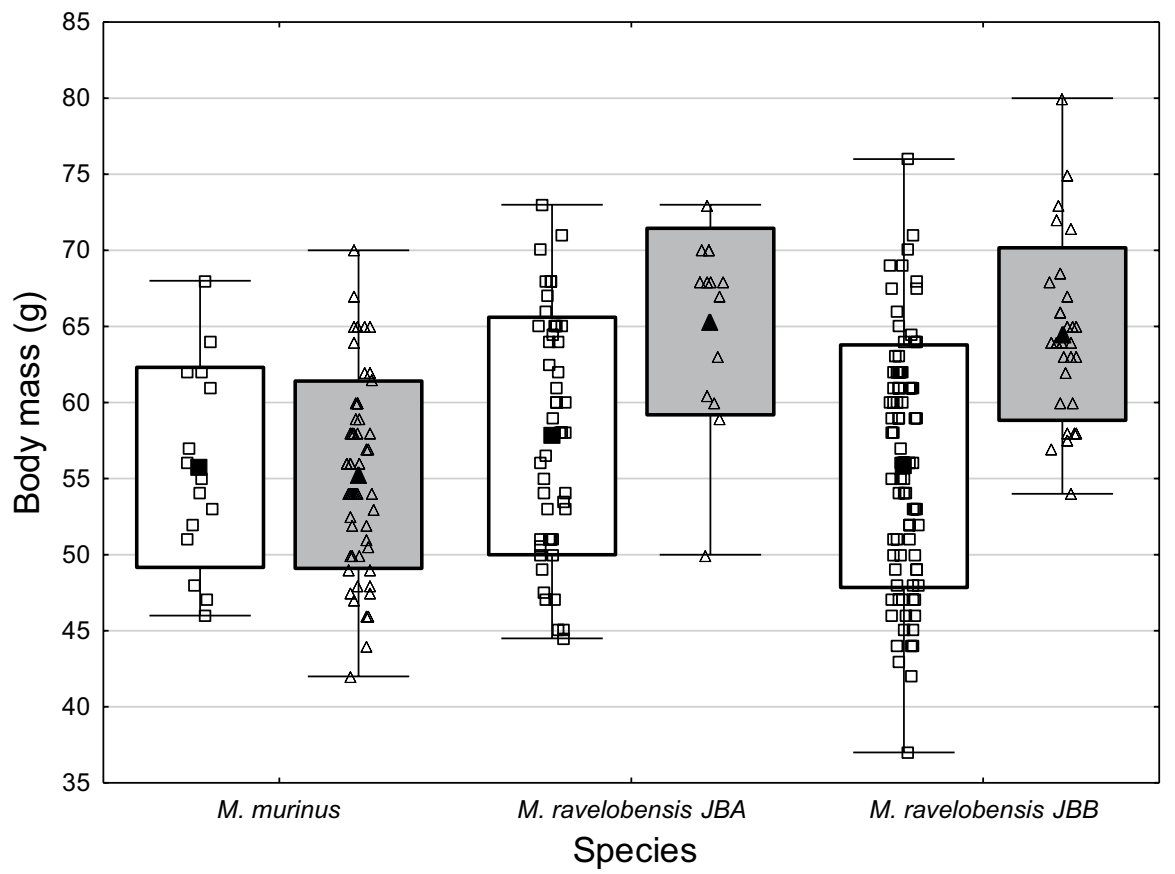

Fig. 7 Body mass of adult females that conceived (gray) or did not conceive (white) during the first 4 main weeks of reproductive activity in M. murinus and for Microcebus ravelobensis (JBA and JBB separately) during 17 years between 1995 and 2015 in Ankarafantsika, Madagascar. Shown are means (filled triangles and squares), quartiles (box), minimum, maximum (whiskers), and individual values (open triangles and squares).

variation in the LEC in the best models (Estimate body mass $>0.14, \mathrm{SE}<0.035, p<$ 0.0001, Appendix S5).

The vast majority of early-conceiving adult Microcebus ravelobensis $(96 \%, n$ $=43 / 45)$ had a body mass $>55 \mathrm{~g}$. Nevertheless, this was also the case for $54 \%$ ( $n=71 / 131$ ) of the non-conceiving adult females (Fig. 7). Among these heavier but non-conceiving adult females, 18 (25\%) had a later estrus, 17 females (24\%) had a second estrous period after the first, and eight females (11\%) showed some indication of previous and prolonged reproductive activity (pregnancy or lactation) between April and June of the same year. No further reproductive details are available for the remaining 28 females due to a lack of sufficient capture data. We inferred a second estrus by trapping females with an open vulva again $(n=27)$ after $2-9$ weeks, with a peak at $4(n=13)$ and $5(n=8)$ weeks for $M$. ravelobensis.

In contrast, body mass did not impact the LEC (in weeks 38-41) of adult female M. murinus (GLMM, Estimate $=0.0012$, $\mathrm{SE}=0.0585, p=0.9840$, Fig. 7). However, among all 31 climatic variables, minimum temperatures in April and maximum temperatures in February had a positive effect on the LEC of M. murinus (Estimate $_{\operatorname{minT} / \mathrm{Apr}}=0.5796, \mathrm{SE}=0.2758, p=0.0356$; Estimate $_{\operatorname{maxT} / \mathrm{Feb}}$ 
$=0.9062, \mathrm{SE}=0.3381, p=0.0074)$, whereas maximum temperatures in November and May had a negative effect on the LEC $\left(\right.$ Estimate $_{\operatorname{maxT} / \mathrm{Nov}}=-0.556, \mathrm{SE}$ $=0.276, p=0.0439$, Estimate maxT $/$ May $=-0.8123, \mathrm{SE}=0.3727, p=0.0293$, Appendix S6). When we combined these four variables in a full model, only the average maximum temperature in February was retained as significant predictor in the best models (Appendix S7). Essentially, the LEC of adult M. murinus increased with increasing average maximum temperature in February (Fig. 8).

Of the 20 adult female Microcebus murinus that did not conceive early, seven $(35 \%)$ had their estrus shortly after these 4 first main weeks of the reproductive season, and three females $(15 \%)$ had a second estrus after a first unsuccessful estrus after about 3 weeks $(n=1), 5$ weeks $(n=1)$, or 6 weeks $(n=1)$. No further reproductive details are available for the remaining ten females.

\section{Discussion}

\section{Dynamics of Reproductive Seasonality}

We detected long-term reproductive seasonality as an uneven distribution of estrus, pregnancy, and lactation during the year in two sympatric mouse lemur species (Microcebus ravelobensis, M. murinus) in northwestern Madagascar. The main mating season led to a first period of pregnancies in October-November (weeks 40-48) followed by a lactation period in November-January (weeks 45-5). We detected a second set of pregnancies in January-February (M. murinus: weeks 3-9) and in March (M. ravelobensis: weeks 10-13), corroborating a previous report of polyestry and a second litter of mouse lemurs at this study site (Schmelting et al., 2000). $M$.

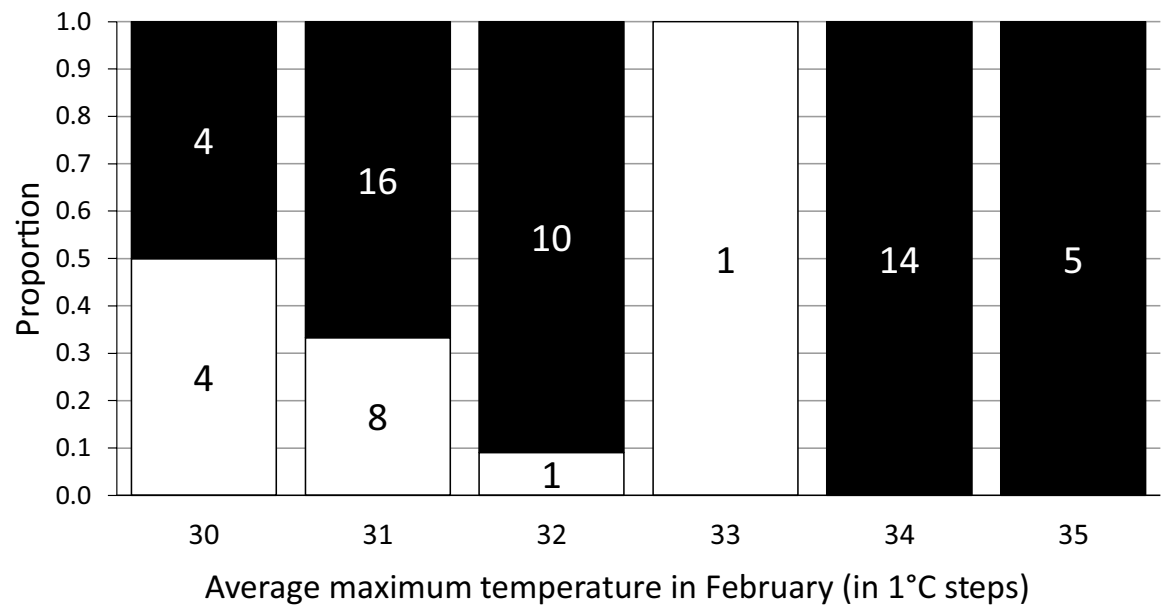

Fig. 8 Proportion of conceiving (in black) or non-conceiving (in white) females of M. murinus in relation to the average maximum temperature during the preceding February for 13 years between 1998 and 2015 in Ankarafantsika, Madagascar. Numbers in bars are the absolute number of females in each category. 
murinus shows regular polyestry with up to three litters in captivity (Perret, 1982; Wrogemann et al., 2001) and at a study site in a southern littoral forest (Mandena; Lahann et al., 2006), but produces only one seasonal litter at a dry forest site (Kirindy; Eberle \& Kappeler, 2004). The number of estrous periods per season has been interpreted as an adaptive response to food availability in each regional ecosystem (Lahann et al., 2006).

Apart from these similarities, the species in this study differed in three key features of their seasonal reproductive patterns. First, Microcebus ravelobensis started annual reproductive activity up to 4 weeks earlier than M. murinus. Second, the yearly onset of reproduction varied between years in $M$. ravelobensis but was constant in M. murinus. Third, some females of M. ravelobensis were found in estrus or pregnant in the first half of the dry season, but we never found females of $M$. murinus in estrus or pregnant at this time. These interspecific differences occurred at the same study site and over the same timespan, suggesting substantial differences in seasonal reproductive regulation in these species. The lack of year-to-year variation in reproductive activation and the high estrous synchrony in M. murinus are in line with strict photoperiodic activation, as confirmed experimentally in this species in captivity (Perret \& Aujard, 2001; Petter-Rousseaux, 1975; Radespiel \& Zimmermann, 2001), even under resource restrictions (Canale et al., 2012), as well as at other sites in Madagascar (Kirindy: Eberle \& Kappeler, 2004, Mandena: Lahann et al., 2006). Such regulation, however, cannot fully explain the observed year-to-year changes in reproductive activation in $M$. ravelobensis. Instead, these findings suggest a flexible response to environmental changes. Year-to-year variations in reproductive activation were also observed in $M$. rufus inhabiting the southeastern montane rainforests, and were also suggested to be related to environmental variations, although those variations were not specified further (Blanco, 2011). We observed earlier activation (weeks 34-35) in years with low rainfall in February and the entire rainy season, and later activation (weeks 36-37) in years of high rainfall in February and the entire rainy season. This relationship is unexpected: more rainfall in February should lead to a higher resource abundance during the late rainy season, which should facilitate seasonal fattening and thereby an increase in body condition before the onset of the lean dry season (Schmid \& Kappeler, 1998). Good body condition, if maintained throughout the subsequent months, should allow reproduction to start rather earlier than later (Randrianambinina et al., 2003).

The late reproductive activation in years of high rainfall could in principle be the result of two different scenarios. The first explanation is that it could result from extended reproductive activity during the late rainy season, e.g., in the form of a potential third litter. In years of high rainfall/resource availability in the late rainy season, females of $M$. ravelobensis may postpone the subsequent reproductive activation by a few weeks for energetic reasons. The occasional observation of pregnant $M$. ravelobensis during the first half of the dry season confirms the existence of some seasonal reproductive plasticity in M. ravelobensis (Figure 2b, Randrianambinina et al., 2003). An opportunistic temporal extension of breeding into the subsequent dry season in response to favorable rainfall could be advantageous if yearto-year climatic fluctuations are high. This seems to be the case in Ampijoroa where the total rainfall per rainy season varied between $971 \mathrm{~mm}$ (in 2002) and $3689 \mathrm{~mm}$ 
(in 2015) during the study. Unfortunately, a more formal test of this "reproductive opportunism hypothesis" is currently not possible due to the very small dataset of 14 pregnancies that were documented for $M$. ravelobensis during the first half of the dry season, and the potential risk that we may have overlooked other such cases during these months. A contrasting explanation could be that females postponed reproductive activation in some years, when heavy rainfall coincided with cyclones that destroyed or diminished the resources in the forest, as shown in southeastern Madagascar (Dunham et al., 2011; Ehrhart \& Overdorff, 2008; Lewis \& Bannar-Martin, 2012; Wright, 1999). A negative impact of cyclones on lemur reproduction or body mass has previously been shown for Propithecus edwardsi (Dunham et al., 2011), Varecia rubra (Ratsisetraina, 2013), Lemur catta (Fardi et al., 2018), but was not found for P. verreauxi (Lewis \& Rakotondranaivo, 2011). However, we documented no large-scale vegetation damage in the study sites after any rainy season during our study, and it is therefore unclear whether such a mechanism may have affected resource availability (e.g., food or shelter) or the body condition of mouse lemurs in some years. More detailed longitudinal records of female reproductive investment and the incidence of third litters in years of high or low rainfall and cyclones are needed to thoroughly test these two contrasting hypotheses.

\section{Influence of Age and Species on Reproduction}

Age impacted reproduction in different ways in the two species. Whereas young and adult females of Microcebus murinus showed a very similar temporal distribution of estrus and pregnancies during the second half of the dry season, adult $M$. ravelobensis started estrus up to 4 weeks earlier than young females did. Young M. ravelobensis showed a reproductive schedule like that of young $M$. murinus but not like that of older conspecifics. M. murinus reach sexual maturation at an age of about 8 months (Hohenbrink et al., 2015; Martin, 1972), and young females can breed successfully during their first year of life (Perret, 1990; Radespiel \& Zimmermann, 2003). Given that (1) growth and development may be slightly delayed under the harsh environmental conditions in the wild (Bauer et al., 2009; Canale et al., 2012), and (2) we inferred births indirectly in $M$. ravelobensis by capture of lactating females from calendar week 45 onwards (mid November), we can expect to capture estrous young M. ravelobensis from calendar week 37 onwards (mid-September, like M. murinus) but not much earlier.

This study also showed that estrus was frequently observed in adult Microcebus ravelobensis for an extended period, spanning 13 weeks (weeks 35-47) in comparison to only 5 weeks (weeks 38-42) in M. murinus (Randrianambinina et al., 2003). This finding can partly be explained as result of a lower number of early conceptions in adult female $M$. ravelobensis than in $M$. murinus, as we observed in each year for which there were sufficient data (Fig. 6). One possible explanation for these different conception rates builds on a long-term adaptation of $M$. ravelobensis to northwestern forest environments (Olivieri et al., 2007) and the reduced role of photoperiodic reproductive regulation in $M$. ravelobensis. If photoperiodic constraints are relaxed, female $M$. ravelobensis may resume cycling flexibly after a refractory period, similar 
to the endogenously regulated testes growth in males that starts even before the transition to long days, shown in captive M. murinus and free-living M. ravelobensis from Ampijoroa (Perret, 2000; Rina Evasoa et al., 2018). However, females may not necessarily conceive during the first estrus if environmental conditions, individual access to resources, or internal physiological states are not favorable. Such reproductive plasticity may be advantageous in habitats of unpredictable but moderately high resource abundance and favorable climatic conditions, even within the dry season, such as appear to be present in northwestern Madagascar (Jury, 2003; Rauh, 1992; Rina Evasoa et al., 2018; Thorén et al., 2011). The observation of some pregnancies more than 1 month earlier in M. ravelobensis (from week 36 onwards) than in M. murinus (from week 43 onwards) suggests that such plasticity may lead to successful early reproduction in at least a subset of females. Future studies should investigate whether such an early start conveys further advantages, for example by allowing females to produce a third litter in the upcoming rainy season, and thereby potentially increasing female reproductive success in that particular year.

In contrast to Microcebus ravelobensis, $M$. murinus most likely evolved in (south) western Madagascar (Blair et al., 2014) and should be adapted to aridity, with the comparatively lower amounts of yearly rainfall, lower minimum temperatures and therefore generally harsher environmental conditions that characterize those forests during the longer dry season (Dammhahn \& Kappeler, 2008; Sorg \& Rohner, 1996). In those parts of the island, females of sufficient body condition even hibernate to reduce energy expenditure during the first half of the dry season (Dausmann, 2014; Dausmann et al., 2009; Schmid, 1999; Schmid \& Kappeler, 1998), but this is not observed in northwestern Madagascar (Randrianambinina et al., 2003; Thorén et al., 2011). The stronger climatic constraints in western Madagascar are reflected in the regular monoestrous reproduction of $M$. murinus within a very short breeding season in that region (Eberle \& Kappeler, 2004). Under such conditions, large individual reproductive plasticity should not be selected for. Instead, selection probably favors highly synchronous reproductive schedules, with the one litter being successfully reared and weaned during the relatively short period of maximum food abundance. M. murinus probably colonized northwestern Madagascar only relatively recently, within the Late Pleistocene (Blair et al., 2014; Schneider et al., 2010). We hypothesize that the high reproductive synchrony of female M. murinus in northwestern Madagascar may result from its original adaptation to the harsher climates in western Madagascar rather than an adaptive response to the climatic conditions prevailing in northwestern Madagascar. Interestingly, a study of M. griseorufus also revealed individual variation in the expression of seasonal polyestry in southwestern Madagascar, and argued that flexible reproduction could be an adaptation to environmental unpredictability at that site and a result of differential energy supply for individual females (Blanco et al., 2015).

\section{Influence of Body Mass and Climate on Conception Likelihoods}

Our study revealed that body mass positively influenced the likelihood of early conception (LEC) in adult Microcebus ravelobensis, but not in M. murinus. Low 
body condition and nutritional impairments can negatively impact reproduction and disturb the regular cycle of female mammals (e.g., Childs et al., 2021; Dunn \& Moss, 1992; Meyer \& Coenen, 2009). However, about half of all adult $M$. ravelobensis without early conception had a body mass comparable to those of early-conceiving conspecifics (Fig. 7). It is possible, though, that some of them were just large but did not have a particularly high body condition. Unfortunately, we did not measure body size routinely alongside body mass, precluding the calculation of body condition for all females. Nevertheless, the lack of early reproduction in these females was partly due to (1) a slight delay in estrus (i.e., low synchrony), (2) failed conception in a first estrus followed by a second estrus after a median of 4 weeks, and (3) delayed onset of estrus in combination with prolonged reproductive activity after the end of the previous rainy season.

Whereas we detected no consistent climatic effect on the LEC in Microcebus ravelobensis when we accounted for body mass, the average maximum temperatures in February but not body mass positively affected the LEC of M. murinus. There are at least two potential pathways for how temperatures in February may have affected subsequent reproduction of M. murinus. First, if high daily temperatures reflect higher solar radiation, higher maximum temperatures may correspond to higher photosynthetic rates and plant productivity (Lawlor, 1995), which may in turn provide more resources for females that have to build up energy reserves for the subsequent lean season and for reproduction (Vuarin et al., 2015; Wright, 1999). Second, daily temperatures regulate the levels and periods of activity and inactivity (i.e., torpor) in M. murinus (Schmid, 2000; Thorén et al., 2011). They may also trigger the timing of the transition from breeding to a "winter phenotype", as mouse lemurs, like several other mammals and birds, rely on reducing energy expenditure during times of reduced energy availability (the dry season), which could potentially impact subsequent reproductive performance (Caro et al., 2013, Vuarin et al. 2015). However, more data are clearly needed to evaluate these two non-exclusive environmental explanations for the variations in the early-conception likelihood among M. murinus.

Finally, the high variation in inter-estrous intervals (from 2-9 weeks) suggests that some females of Microcebus ravelobensis may have had non-ovulatory cycles at the beginning of the reproductive season (Chatdarong et al., 2006). In captivity, $M$. murinus and $M$. lehilahytsara can have two to three successive estrous cycles within one reproductive season that can last between 42 and 68 days (Radespiel \& Zimmermann, 2001; Wrogemann et al., 2001), but shorter estrous cycle lengths (means $=38-62$ days) have been reported from a French colony, in particular for isolated females (Perret, 1994). The comparison of the observed intervals with these published values suggests that the very short interestrous intervals ( $<5$ weeks or $<35$ days) of some female $M$. ravelobensis may have resulted from non-ovulatory cycles at the beginning of the mating season. We cannot determine whether such non-ovulatory cycles are a by-product of the increased and potentially adaptive reproductive plasticity in $M$. ravelobensis, or a sign of hormonal dysregulation based on this dataset. Future work is needed to better understand the reproductive physiology of female $M$. ravelobensis in comparison to their sympatric congeners. 


\section{Conclusions}

This study revealed signals of disparate regulation of seasonal reproduction in two sympatric mouse lemur species in northwestern Madagascar that may represent two different evolutionary reproductive strategies. While one species (Microcebus murinus) was heavily constrained by strict photoperiodic regulation of reproductive activation, the other species (M. ravelobensis) showed a considerable degree of environmentally driven reproductive plasticity. It appears that early reproduction is a flexible option for female $M$. ravelobensis that allows them to adjust reproductive investment in response to resource availability and internal state. This flexibility may result in two or three litters per year according to the circumstances. However, reproductive plasticity does not preclude a genetic component in the regulation of reproductive seasonality in female $M$. ravelobensis. An earlier study suggested a strong phylogenetic background in mouse lemur reproductive schedules (Rina Evasoa et al., 2018). A phylogenetic constraint could also explain why $M$. murinus has not yet changed its process of reproductive activation, either under captive conditions where high quality food is available all year round, or when living in a less harsh and seasonal environment such as the forests in northwestern Madagascar. The co-occurrence of both species in various study sites in the region (this study, Andriatsitohaina et al., 2019; Rakotondravony \& Radespiel, 2009; Steffens \& Lehman, 2018), confirmed over a period of 24 years in the case of the deciduous forest site JBA (this study), suggests that the two modes of reproductive regulation are successful alternative reproductive pathways within one genus of primates. Future studies, however, are needed to investigate the interplay between environmental factors, species-specific female reproductive timing and success, population growth, and the dynamic spatiotemporal partitioning of these mouse lemur species in sites of sympatry. Finally, we cannot easily predict which strategy is better adapted for coping with ongoing and future transformations in their natural environments, in particular to those related to climate change (Brown \& Yoder, 2015).

Supplementary Information The online version contains supplementary material available at https://doi. org/10.1007/s10764-021-00261-z.

Acknowledgements We dedicate this article to Elke Zimmermann who headed this long-term project from the beginning until her early death in July 2019. Without her, this study would have never become possible and we would know so much less about small nocturnal lemurs. We also thank the Ministère de L'Environnement et du Développement Durable (previously: Ministère de l'Environnement, de l'Ecologie et des Forêts de Madagascar), especially the former Direction du Système des Aires Protégées and the actual Direction de Gestion de Ressources Naturelles Renouvelables et des Ecosystèmes, Madagascar National Parks, all previous and actual directors and research officers of the Ankarafantsika National Park, and all authorities that were involved and facilitated this long-term work over these many years. We are thankful to the local staff of Durrell Wildlife Conservation Trust in Ankarafantsika for sharing rainfall and temperature data over the years. Furthermore, we are indebted to all long-term partners and students of the University of Mahajanga, the University of Antananarivo, and the University of Veterinary Medicine Hannover, Foundation, who kept this collaboration alive and going throughout the last 25 years. In particular, we emphasize the support of the late Elke Zimmermann, the late Berthe Rakotosamimanana, the late Olga Ramilijaona, Noromalala Raminosoa Rasoamampionona, Daniel Rakotondravony, and Hanta Razafindraibe over the years. Many students and field assistants helped to collect the reproductive records for the mouse lemurs included in this study. Among these, particular thanks go to Petra Maurer (née Ehresmann), Vera Zietemann, Barthel Schmelting, Pia Braune, Wiebke Puvogel 
(née Reimann), Sandra Mester, Marine Joly, Sandra Thorén, Franziska Welling (née Quietzsch), Sharon Kessler, and Annette Klein for their major contribution to long-term trapping in JBA and JBB. We also appreciate the technical help of Elisabeth Engelke in generating the long-term database of female reproductive records. Finally, we acknowledge the helpful comments of two anonymous reviewers, guest editor Marina Scheumann, and the Editor-in-Chief Joanna M. Setchell on a previous version of the manuscript, and we thank Frances C. Sherwood-Brock for correcting the English.

Authors' contributions UR conceived the study. UR, BR, SR, RR collected data for the study. UR analyzed the data. UR drafted the manuscript and BR, SR, RR revised the manuscript.

Funding Open Access funding enabled and organized by Projekt DEAL.

Open Access This article is licensed under a Creative Commons Attribution 4.0 International License, which permits use, sharing, adaptation, distribution and reproduction in any medium or format, as long as you give appropriate credit to the original author(s) and the source, provide a link to the Creative Commons licence, and indicate if changes were made. The images or other third party material in this article are included in the article's Creative Commons licence, unless indicated otherwise in a credit line to the material. If material is not included in the article's Creative Commons licence and your intended use is not permitted by statutory regulation or exceeds the permitted use, you will need to obtain permission directly from the copyright holder. To view a copy of this licence, visit http://creativecommons.org/licen ses/by/4.0/.

\section{References}

Andriatsitohaina, B., Ramsay, M. S., Kiene, F., Lehman, S. M., Rasoloharijaona, S., Rakotondravony, R., \& Radespiel, U. (2019). Ecological fragmentation effects in mouse lemurs and small mammals in northwestern Madagascar. American Journal of Primatology, 82, e23059. https://doi.org/ 10.1002/ajp.23059.

Bauer, B., Dittami, J., \& Huber, S. (2009). Effects of nutritional quality during early development on body weight and reproductive maturation of guinea pigs (Cavia aperea $f$. porcellus). General and Comparative Endocrinology, 161(3), 384-389. https://doi.org/10.1016/j.ygcen.2009.02.003.

Blair, C., Heckman, K. L., Russell, A. L., \& Yoder, A. D. (2014). Multilocus coalescent analyses reveal the demographic history and speciation patterns of mouse lemur sister species. BMC Evolutionary Biology, 14(1), 57. https://doi.org/10.1186/1471-2148-14-57.

Blanco, M. B. (2008). Reproductive schedules of female Microcebus rufus at Ranomafana National Park, Madagascar. International Journal of Primatology, 29(2), 323-338. https://doi.org/10. 1007/s10764-008-9238-9.

Blanco, M. B. (2011). Timely estrus in wild brown mouse lemur females at Ranomafana National Park, southeastern Madagascar. American Journal of Physical Anthropology, 145(2), 311-317. https://doi.org/10.1002/ajpa.21503.

Blanco, M. B., Rasoazanabary, E., \& Godfrey, L. R. (2015). Unpredictable environments, opportunistic responses: Reproduction and population turnover in two wild mouse lemur species (Microcebus rufus and M. griseorufus) from eastern and western Madagascar. American Journal of Primatology, 77(9), 936-947. https://doi.org/10.1002/ajp.22423.

Brockman, D. K., \& van Schaik, C. P. (2005). Seasonality and reproductive function. In D. K. Brockman \& C. P. van Schaik (Eds.), Seasonality in primates: Studies of living and extinct human and non-human primates (pp. 269-306). Cambridge University Press.

Brown, J. L., \& Yoder, A. D. (2015). Shifting ranges and conservation challenges for lemurs in the face of climate change. Ecology and Evolution, 5(6), 1131-1142. https://doi.org/10.1002/ece3. 1418.

Buchanan, K., Burt de Perera, T., Carere, C., Carter, T., Hailey, A., Hubrecht, R., et al (2012). Guidelines for the treatment of animals in behavioural research and teaching. Animal Behaviour, 83(1), 301-309. https://doi.org/10.1016/j.anbehav.2011.10.031.

Canale, C. I., Huchard, E., Perret, M., \& Henry, P.-Y. (2012). Reproductive resilience to food shortage in a small heterothermic primate. PLOS ONE, 7(7), e41477. https://doi.org/10.1371/journal.pone. 0041477. 
Caro, S. P., Schaper, S. V., Hut, R. A., Ball, G. F., \& Visser, M. E. (2013). The case of the missing mechanism: how does temperature influence seasonal timing in endotherms? PLoS Biology, 11(4), e1001517. https://doi.org/10.1371/journal.pbio.1001517.

Chatdarong, K., Lohachit, C., Kiartmanakul, S., Axner, E., \& Forsberg, C. L. (2006). Cervical patency during non-ovulatory and ovulatory estrus cycles in domestic cats. Theriogenology, 66(4), 804-810. https://doi.org/10.1016/j.theriogenology.2006.01.053.

Childs, G. V., Odle, A. K., MacNicol, M. C., \& MacNicol, A. M. (2021). The importance of leptin to reproduction. Endocrinology, 162(2), bqaa204. https://doi.org/10.1210/endocr/bqaa204.

Dammhahn, M., \& Kappeler, P. M. (2008). Comparative feeding ecology of sympatric Microcebus berthae and M. murinus. International Journal of Primatology, 29, 1567-1589. https://doi.org/10.1007/ s10764-008-9312-3.

Dausmann, K. H. (2014). Flexible patterns in energy savings: heterothermy in primates. Journal of Zoology, 292(2), 101-111. https://doi.org/10.1111/jzo.12104.

Dausmann, K. H., Glos, J., \& Heldmaier, G. (2009). Energetics of tropical hibernation. Journal of Comparative Physiology B-Biochemical Systemic and Environmental Physiology, 179(3), 345-357. https://doi.org/10.1007/s00360-008-0318-0.

Di Bitetti, M. S., \& Janson, C. H. (2000). When will the stork arrive? Patterns of birth seasonality in Neotropical primates. American Journal of Primatology, 50, 109-130.

Dunham, A. E., Erhart, E. M., \& Wright, P. C. (2011). Global climate cycles and cyclones: consequences for rainfall patterns and lemur reproduction in southeastern Madagascar. Global Change Biology, 17, 219-227. https://doi.org/10.1111/j.1365-2486.2010.02205.x.

Dunn, T. G., \& Moss, G. E. (1992). Effects of nutrient deficiencies and excesses on reproductive efficiency of livestock. Journal of Animal Science, 70(5), 1580-1593. https://doi.org/10.2527/1992. $7051580 x$.

Eberle, M., \& Kappeler, P. M. (2004). Sex in the dark: determinants and consequences of mixed male mating tactics in Microcebus murinus, a small solitary nocturnal primate. Behavioral Ecology and Sociobiology, 57, 77-90. https://doi.org/10.1007/s00265-004-0826-1.

Ehrhart, E. M., \& Overdorff, D. J. (2008). Population demography and social structure changes in Eulemur fulvus rufus from 1988 to 2003. American Journal of Physical Anthropology, 136, 183-193. https://doi.org/10.1002/ajpa.20793.

Ellis, K. M., Abondano, L. A., Montes-Rojas, A., Link, A., \& Di Fiore, A. (2021). Reproductive seasonality in two sympatric primates (Ateles belzebuth and Lagothrix lagotricha poeppigii) from Amazonian Ecuador. American Journal of Primatology, 83(1), e23220. https://doi.org/10.1002/ajp.23220.

Fardi, S., Sauther, M. L., Cuozzo, F. P., Jacky, I. A. Y., \& Bernstein, R. M. (2018). The effect of extreme weather events on hair cortisol and body weight in a wild ring-tailed lemur population (Lemur catta) in southwestern Madagascar. American Journal of Primatology, 80, e22731. https://doi.org/10. 1002/ajp.22731.

Fernandez-Duque, E., Rotundo, M., \& Ramirez-Llorens, P. (2002). Environmental determinants of birth seasonality in night monkeys (Aotus azarai) of the Argentinean Chaco. International Journal of Primatology, 23(3), 639-656. https://doi.org/10.1023/A:1014929902923.

Hämäläinen, A. (2014). Sex-Specific Aging. Sex differences in survival and health in a wild primate population. PhD dissertation,Georg-August-Universität Göttingen. http://hdl.handle.net/11858/ 00-1735-0000-0023-9606-6.

Heldstab, S. A., van Schaik, C. P., Muller, D. W. H., Rensch, E., Lackey, L. B., Zerbe, P., et al (2021). Reproductive seasonality in primates: patterns, concepts and unsolved questions. Biological Reviews, 96(1), 66-88. https://doi.org/10.1111/brv.12646.

Hohenbrink, S., Zimmermann, E., \& Radespiel, U. (2015). Need for speed: sexual maturation precedes social maturation in gray mouse lemurs. American Journal of Primatology, 77(10), 1049-1059. https://doi.org/10.1002/ajp.22440.

Holm, S. (1979). A simple sequentially rejective multiple test procedure. Scandinavian Journal of Statistics, 6(2), 65-70 https://www.jstor.org/stable/4615733.

Hotaling, S., Foley, M. E., Lawrence, N. M., Bocanegra, J., Blanco, M. B., Rasoloarison, R., et al (2016). Species discovery and validation in a cryptic radiation of endangered primates: coalescent-based species delimitation in Madagascar's mouse lemurs. Molecular Ecology, 25(9), 2029-2045. https:// doi.org/10.1111/mec.13604.

Huang, Z. P., Cui, L. W., Scott, M. B., Wang, S. J., \& Xiao, W. (2012). Seasonality of reproduction of wild black-and-white snub-nosed monkeys (Rhinopithecus bieti) at Mt. Lasha, Yunnan, China. Primates, 53(3), 237-245. https://doi.org/10.1007/s10329-012-0305-7. 
Janson, C., \& Verdolin, J. (2005). Seasonality of primate births in relation to climate. In D. K. Brockman \& C. P. van Schaik (Eds.), Seasonality in primates: Studies of living and extinct human and nonhuman primates (pp. 307-350). Cambridge University Press.

Jury, M. R. (2003). The climate of Madagascar. In S. M. Goodman \& J. P. Benstead (Eds.), The Natural History of Madagascar (pp. 75-87). University of Chicago Press.

Lahann, P., Schmid, J., \& Ganzhorn, J. U. (2006). Geographic variation in populations of Microcebus murinus in Madagascar: resource seasonality or Bergmann's Rule? International Journal of Primatology, 27(4), 983-999. https://doi.org/10.1007/s10764-006-9055-y.

Lawlor, D. W. (1995). Photosynthesis, productivity and environment. Journal of Experimental Botany, 46(special issue), 1449-1461. https://doi.org/10.1093/jxb/46.special_issue.1449.

Lewis, R. J., \& Bannar-Martin, K. H. (2012). The impact of cyclone Fanele on a tropical dry forest in Madagascar. Biotropica, 44, 135-140. https://doi.org/10.1111/j.1744-7429.2011.00799.x.

Lewis, R. J., \& Rakotondranaivo, F. (2011). The impact of cyclone Fanele on sifaka body condition and reproduction in the tropical dry forest of western Madagascar. Journal of Tropical Ecology, 27, 429-432. https://doi.org/10.1017/S0266467411000083.

Lindburg, D. G. (1987). Seasonality of reproduction in primates. In G. Mitchell \& J. Erwin (Eds.), Comparative Primate Biology, Vol. 2B: Behavior, Cognition and Motivation (pp. 167-218). Alan R. Liss, Inc.

Martin, R. D. (1972). A preliminary field-study of the lesser mouse lemur (Microcebus murinus J.F. Miller 1777). Zeitschrift für Tierpsychologie, 9, 43-89.

Meyer, H., \& Coenen, M. (2009). Einfluss der Ernährung auf die Fruchtbarkeit. In W. Busch \& K. Zerobin (Eds.), Fruchtbarkeitskontrolle bei Groß- und Kleintieren (pp. 40-60). Enke Verlag.

Olivieri, G., Zimmermann, E., Randrianambinina, B., Rasoloharijaona, S., Rakotondravony, D., Guschanski, K., \& Radespiel, U. (2007). The ever-increasing diversity in mouse lemurs: three new species in north and northwestern Madagascar. Molecular Phylogenetics and Evolution, 43(1), 309-327. https://doi.org/10.1016/j.ympev.2006.10.026.

Pereira, M. E. (1993a). Agonistic interaction, dominance relation, and ontogenetic trajectories in ringtailed lemurs. In M. E. Pereira \& L. A. Fairbanks (Eds.), Juvenile Primates: Life History, Development, and Behavior (pp. 285-305). Oxford University Press.

Pereira, M. E. (1993b). Seasonal adjustment of growth rate and adult body weight in ringtailed lemurs. In P. M. Kappeler \& J. U. Ganzhorn (Eds.), Lemur Social Systems and their Ecological Basis (pp. 205-221). Plenum Press.

Perret, M. (1982). Influence du groupement social sur la reproduction de la femelle de Microcebus murinus (Miller, 1777). Zeitschrift für Tierpsychologie, 60, 47-65.

Perret, M. (1990). Influence of social factors on sex ratio at birth, maternal investment and young survival in a prosimian primate. Behavioral Ecology and Sociobiology, 27, 447-454. https://doi.org/10.1007/ BF00164072.

Perret, M. (1992). Environmental and social determinants of sexual function in the male lesser mouse lemur (Microcebus murinus). Folia Primatologica, 59, 1-25.

Perret, M. (1994). Social signals and their influences on reproduction in the lesser mouse lemur. In J. J. Roeder, B. Thierry, J. R. Anderson, \& N. Herrenschmidt (Eds.), Current Primatology. Vol.2 Social Development, Learning and Behaviour (pp. 47-55). Universite Louis Pasteur.

Perret, M. (2000). Reproduction saisonnière et succès reproducteur chez un prosimien malgache, Microcebus murinus. Primatologie, 3, 45-84.

Perret, M., \& Aujard, F. (2001). Regulation by photoperiod of seasonal changes in body mass and reproductive function in gray mouse lemurs (Microcebus murinus): differential responses by sex. International Journal of Primatology, 22, 5-24. https://doi.org/10.1023/A:1026457813626.

Petter-Rousseaux, A. (1975). Activité sexuelle de Microcebus murinus (Miller, 1777) soumis à des régimes photopériodiques expérimentaux. Annales de Biologie Animale, Biochimie, Biophysique, 15, 503-508.

Radespiel, U., \& Zimmermann, E. (2001). Dynamics of estrous synchrony in captive gray mouse lemurs (Microcebus murinus). International Journal of Primatology, 22, 71-90.

Radespiel, U., \& Zimmermann, E. (2003). The influence of familiarity, age, experience and female mate choice on pregnancies in captive grey mouse lemurs. Behaviour, 140, 301-318. https://doi.org/10. 1023/A:1026466015443.

Radespiel, U., Ehresmann, P., \& Zimmermann, E. (2003). Species-specific usage of sleeping sites in two sympatric mouse lemur species (Microcebus murinus and M. ravelobensis) in northwestern Madagascar. American Journal of Primatology, 59, 139-151. https://doi.org/10.1002/ajp.10071. 
Rakotondravony, R., \& Radespiel, U. (2009). Varying patterns of coexistence of two mouse lemur species (Microcebus ravelobensis and M. murinus) in a heterogeneous landscape. American Journal of Primatology, 71(11), 928-938. https://doi.org/10.1002/ajp.20732.

Randrianambinina, B., Rakotondravony, D., Radespiel, U., \& Zimmermann, E. (2003). Seasonal changes in general activity, body mass and reproduction of two small nocturnal primates: a comparison of the golden brown mouse lemur (Microcebus ravelobensis) in northwestern Madagascar and the brown mouse lemur (Microcebus rufus) in eastern Madagascar. Primates, 44, 321-331. https://doi. org/10.1007/s10329-003-0046-8.

Ratsisetraina, R. I. (2013). Population recovery of two diurnal lemur species, Varecia rubra and Eulemur albifrons, following cyclonic disturbance in Masoala National Park, Madagascar. Lemur News, 17, 27-32.

Rauh, W. (1992). Zur Klima- und Vegetationszonierung Madagaskars. In A. Bittner (Ed.), Madagaskar: Mensch und Natur im Konflikt (pp. 31-53). Birkhäuser Verlag.

Richard, A. F., \& Dewar, R. E. (1991). Lemur ecology. Annual Review of Ecology and Systematics, 22, 145-175. https://doi.org/10.1146/annurev.es.22.110191.001045.

Rina Evasoa, M., Radespiel, U., Hasiniaina, A. F., Rasoloharijaona, S., Randrianambinina, B., Rakotondravony, R., \& Zimmermann, E. (2018). Variation in reproduction of the smallest-bodied primate radiation, the mouse lemurs (Microcebus spp.): A synopsis. American Journal of Primatology, 80(7), e22874. https://doi.org/10.1002/ajp.22874.

Rode-Margono, E. J., Nekaris, K. A. I., Kappeler, P. M., \& Schwitzer, C. (2015). The largest relative testis size among primates and aseasonal reproduction in a nocturnal lemur, Mirza zaza. American Journal of Physical Anthropology, 158(1), 165-169. https://doi.org/10.1002/ajpa.22773.

RStudio Team. (2020). RStudio: Integrated Development for R. RStudio, PBC, URL https://www. rstudio.com/.

Savini, T., Boesch, C., \& Reichard, U. H. (2008). Home-range characteristics and the influence of seasonality on femalereproduction in white-handed gibbons (Hylobates lar) at Khao Yai National Park, Thailand. American Journal of PhysicalAnthropology, 135(1), 1-12. https://doi.org/10. 1002/ajpa.20578.

Schmelting, B., Ehresmann, P., Lutermann, H., Randrianambinina, B., \& Zimmermann, E. (2000). Reproduction of two sympatric mouse lemur species (Microcebus murinus and M. ravelobensis) in north-west Madagascar: first results of a long term study. In W. R. Lourenço \& S. M. Goodman (Eds.), Diversité et Endémisme à Madagascar (pp. 165-175). Société de Biogéographie.

Schmid, J. (1999). Sex-specific differences in activity patterns and fattening in the gray mouse lemur (Microcebus murinus) in Madagascar. Journal of Mammalogy, 80(3), 749-757. https://doi.org/ $10.2307 / 1383244$.

Schmid, J. (2000). Torpor in the tropics: the case of the gray mouse lemur (Microcebus murinus). Basic and Applied Ecology, 1, 133-139. https://doi.org/10.1078/1439-1791-00019.

Schmid, J., \& Kappeler, P. M. (1998). Fluctuating sexual dimorphism and differential hibernation by sex in a primate, the gray mouse lemur (Microcebus murinus). Behavioral Ecology and Sociobiology, 43, 125-132. https://doi.org/10.1007/s002650050474.

Schneider, N., Chikhi, L., Currat, M., \& Radespiel, U. (2010). Signals of recent spatial expansions in the grey mouse lemur (Microcebus murinus). BMC Evolutionary Biology, 10, 105. https://doi. org/10.1186/1471-2148-10-105.

Schüßler, D., Blanco, M. B., Salmona, J., Poelstra, J., Andriambeloson, J. B., Miller, A., et al (2020). Ecology and morphology of mouse lemurs (Microcebus spp.) in a hotspot of microendemism in northeastern Madagascar, with the description of a new species. American Journal of Primatology, 82(9), e23180. https://doi.org/10.1002/ajp.23180.

Sorg, J. P., \& Rohner, U. (1996). Climate and tree phenology of the dry deciduous forest of the Kirindy Forest. Primate Report, 44, 57-80.

Stanger, K. F., Coffman, B. S., \& Izard, M. K. (1995). Reproduction in Coquerel's Dwarf Lemur (Mirza coquereli). American Journal of Primatology, 36, 223-237. https://doi.org/10.1002/ajp. 1350360306.

Steffens, T. S., \& Lehman, S. M. (2018). Lemur species-specific metapopulation responses to habitat loss and fragmentation. PLOS ONE, 13(5), e0195791. https://doi.org/10.1371/journal.pone. 0195791.

Sterling, E. J. (1994). Evidence for nonseasonal reproduction in wild Aye-Ayes (Daubentonia madagascariensis). Folia Primatologica, 62, 46-53. https://doi.org/10.1159/000156762. 
Stone, A. I., \& Ruivo, L. V. P. (2020). Synchronization of weaning time with peak fruit availability in squirrel monkeys (Saimiri collinsi) living in Amazonian Brazil. American Journal of Primatology, 82(7), e23139. https://doi.org/10.1002/ajp.23139.

Thorén, S., Quietzsch, F., Schwochow, D., Sehen, L., Meusel, C., Meares, K., \& Radespiel, U. (2011). Seasonal changes in feeding ecology and activity patterns of two sympatric mouse lemur species, the gray mouse lemur (Microcebus murinus) and the golden-brown mouse lemur (M. ravelobensis), in northwestern Madagascar. International Journal of Primatology, 32, 566-586. https:// doi.org/10.1007/s10764-010-9488-1.

Vuarin, P., Dammhahn, M., Kappeler, P. M., \& Henry, P. Y. (2015). When to initiate torpor use? Food availability times the transition to winter phenotype in a tropical heterotherm. Oecologia, 179(1), 43-53. https://doi.org/10.1007/s00442-015-3328-0.

Weidt, A., Hagenah, N., Randrianambinina, B., Radespiel, U., \& Zimmermann, E. (2004). The social organisation of the golden-brown mouse lemur (Microcebus ravelobensis). American Journal of Physical Anthropology, 123, 40-51. https://doi.org/10.1002/ajpa.10296.

Wright, P. C. (1999). Lemur traits and Madagascar ecology: coping with an island environment. Yearbook of Physical Anthropology, 42, 31-72.

Wrogemann, D., Radespiel, U., \& Zimmermann, E. (2001). Comparison of reproductive characteristics and changes in body weight between captive populations of rufous and gray mouse lemurs. International Journal of Primatology, 22, 91-108. https://doi.org/10.1023/A:1026418132281.

Zimmermann, E., Cepok, S., Rakotoarison, N., Zietemann, V., \& Radespiel, U. (1998). Sympatric mouse lemurs in North-West Madagascar: A new rufous mouse lemur species (Microcebus ravelobensis). Folia Primatologica, 69, 106-114. https://doi.org/10.1159/000021571.

\section{Authors and Affiliations}

\section{Ute Radespiel $^{1}$ (D) Romule Rakotondravony ${ }^{2,3}$. Solofonirina Rasoloharijaona ${ }^{2,3} \cdot$ Blanchard Randrianambinina ${ }^{2,3}$}

$\triangle$ Ute Radespiel

Ute.radespiel@tiho-hannover.de

1 Institute of Zoology, University of Veterinary Medicine Hannover, Foundation, Buenteweg 17, 30559 Hannover, Germany

2 Ecole Doctorale Ecosystèmes Naturels (EDEN), University of Mahajanga, 5 Rue Georges V Immeuble KAKAL, Mahajanga Be, B.P. 652, 401 Mahajanga, Madagascar

3 Faculté des Sciences, de Technologies et de l'Environnement, University of Mahajanga, Campus universitaire Ambondrona, B.P. 652, 401 Mahajanga, Madagascar 